\title{
CASE STUDY: THE STATE OF INFORMATION SYSTEMS IN AUSTRALIAN CAPITAL TERRITORY UNIVERSITIES
}

\author{
Shirley Gregor \\ School of Accounting \& Business Information Systems, \\ The Australian National University. \\ Shirley.Gregor@anu.edu.au \\ Edward Lewis \\ School of Information Technology and Electrical Engineering, \\ Australian Defence Forces Academy, \\ University of New South Wales. \\ e.lewis@adfa.edu.au

\section{Craig McDonald} \\ School of Information Sciences and Engineering, \\ University of Canberra. \\ Craig.McDonald@canberra.edu.au
}

\begin{abstract}
This paper describes the Information Systems Groups at the Australian Defence Force Academy (ADFA), The Australian National University (ANU), and the University of Canberra (UC). Each group has a distinctive background that reflects its position in Canberra, Australia's seat of federal government. ADFA is essentially a private university for the Australian Defence Organization; ANU was set up to be a national research institution; and the UC group for many years focused on meeting the training needs for computing professionals for the federal government. Despite these distinguishing characteristics, the subject matter taught and researched in the three groups has a large degree of commonality and each group regards itself as 'vibrant' and happy with what it does. A low degree of professionalisation is perceived, however, relative to older disciplines, as there is a disjunct between what is taught as core knowledge and what is taught as research methods, a lack of social prestige, and a lack of acceptance as a discipline with a unique symbol system.
\end{abstract}




\section{INTRODUCTION}

The Australian Capital Territory (ACT) differs from the Australian states in that it is a "territory" rather than a state - a distinction shared also by the Northern Territory. The ACT was chosen as the seat of the Australian Government and the home for its capital city, Canberra, in 1908. A neutral location for the capital and the new territory was selected between Sydney and Melbourne, because of the rivalries among the states that federated to form the nation of Australia in 1901. The territory is less than 100 square kilometres and is tiny compared with the large state of New South Wales that surrounds it. The population of the ACT is approximately 300,000 and almost all its inhabitants live in Canberra, which is home to the three university institutions described in this report. The descriptions of the institutions should be read against this common background of being situated in a relatively new, planned, government city with a smaller population than all but one of the capital cities in the other states in Australia.

The three institutions represented are the Australian National University (ANU), the University of Canberra (UC) and the University College of the University of New South Wales (UNSW) at the Australian Defence Force Academy (UNSW@ADFA). The ACT also has campuses of the Australian Catholic University and Charles Sturt University but as they do not have Information Systems (IS) programs they are not included.

Each of the three authors of the report represent one of the institutions included and they were able to collaborate face-to-face in preparing the report as they are all located within such a small geographical area. The authors are used to working together and interacting around common interests on other occasions. A research assistant, Ahmed Imran, interviewed each of the authors separately as an initial source of information, with the data obtained being supplemented by archival research. The report was then extended and refined by additions from each of the authors and colleagues at the three institutions.

\section{The Universities in this Study}

Table 1 presents some summary statistics for the universities in this study.

\begin{tabular}{|l|l|l|}
\hline University & $\begin{array}{l}\text { Number of full-time } \\
\text { equivalent students }\end{array}$ & $\begin{array}{l}\text { Approximate number of } \\
\text { full-time equivalent staff } \\
\text { (academic and general) }\end{array}$ \\
\hline UNSW@ADFA & $1711(932 \mathrm{u} / \mathrm{g})$ in 2004 & 300 \\
\hline $\begin{array}{l}\text { The Australian National University } \\
(\text { ANU) }\end{array}$ & $>13,920(8,731 \mathrm{u} / \mathrm{g})$ & $>3,600$ \\
\hline University of Canberra (UC) & $6000(4200 \mathrm{u} / \mathrm{g})$ & $>1000$ \\
\hline
\end{tabular}

Table 1 Demographics for the home universities for the IS groups, as of 2005

The academic component of the Australian Defence Force Academy is the University College of the UNSW, which has the status of a Faculty. The University of New South Wales has an agreement with the Department of Defence to provide tertiary education to Officer Cadets and Midshipmen of the armed forces of Australia, New Zealand, Singapore, and Thailand. In effect, it is a private university for the Australian Defence Organisation. However, it also offers postgraduate education to any qualified applicant, not necessarily with any Defence affiliation. 
ANU differs from other contemporary Australian universities in that it was established by an Act of Federal Parliament. On its establishment in 1946 it was given no undergraduate teaching responsibilities. Its mandate was to undertake "postgraduate research and study both generally and in relation to subjects of national importance" (ANU, 2005a, 2005b). Undergraduate teaching was gained only when the ANU joined with the Canberra University College in 1960. The Canberra University College had been in existence for some time as a college of the University of Melbourne. The ANU continues to be one of Australia's most research-intensive universities, with a high ratio of academic staff to students. The ANU was also given an unusual structure, with an Institute of Advanced Studies, which is primarily engaged in research, and 'The Faculties', which undertake undergraduate teaching as well as engaging in postgraduate training and research. Information Systems is situated in the Faculties. The University structure has changed recently, with Colleges formed in January 2006 that more closely integrate the component parts of the Institute and the Faculties.

The University of Canberra was formed by an act of the ACT government in 1990 from the Canberra College of Advanced Education that had been established in 1969. As a College of Advanced Education (CAE), its educational programs focused on professional and para-professional disciplines. As a University it has increased its focus on research.

\section{OVERVIEW OF THE IS PRESENCE IN THE ACT UNIVERSITIES}

Table 2 gives an overview of the Information Systems groups in the three universities.

\begin{tabular}{|l|l|l|c|c|}
\hline University & Administrative Entity & Home Faculty & $\begin{array}{l}\text { Number of } \\
\text { full-time IS } \\
\text { Academics }\end{array}$ & $\begin{array}{l}\text { Number of } \\
\text { IS Students * }\end{array}$ \\
\hline UNSW@ADFA & $\begin{array}{l}\text { IS Group in School of IT and } \\
\text { Electrical Engineering }\end{array}$ & University College & 7.5 & 100 \\
\hline $\begin{array}{l}\text { The Australian } \\
\text { National } \\
\text { University (ANU) }\end{array}$ & $\begin{array}{l}\text { IS Group in School of } \\
\text { Accounting and Business } \\
\text { Information Systems }\end{array}$ & $\begin{array}{l}\text { Economics and } \\
\text { Commerce }\end{array}$ & 6.5 & 100 \\
\hline $\begin{array}{l}\text { University of } \\
\text { Canberra }\end{array}$ & $\begin{array}{l}\text { IS Group in School of } \\
\text { Information Sciences and } \\
\text { Engineering }\end{array}$ & $\begin{array}{l}\text { Business, Law and } \\
\text { Information } \\
\text { Sciences }\end{array}$ & \multicolumn{1}{|c|}{11} & 250 \\
\hline
\end{tabular}

* Approximate number of full-time equivalent students in IS courses, including service courses, not IS programs alone.

Table 2: Demographics for the IS groups (2005)

\section{Australian Defence Force Academy (ADFA)}

Computer Science was taught at the Royal Military College (RMC) Duntroon for some time. Initially, it was presented by the Department of Mathematics but a separate Department of Computer Science, under Vance Gledhill, was in place in the mid 1980s. Whilst still at RMC, the Department introduced a first year IS subject in 1985. In 1986 the Australian Defence Force Academy opened and the University moved from RMC to ADFA. UNSW@ADFA has provided education in Information Systems since its inception in 1986, within the School of Computer Science. Since 1986, each year saw another year added to the IS curriculum, with an Honours year established in 1991. The first postgraduate research student also started in 1991. 
In 1990 there were 120 students in IS first year, with 50 in second year. At that time, the Services were encouraging students to undertake IS or Computer Science studies to at least second year. This 'encouragement' has dropped off since then and the numbers fell to about 30 in IS first year in 2003. Since then the numbers have risen in all years, despite the dip in enrolment in other institutions, to about 65 in First year and 30 in second year.

In 2003, the Schools at UNSW@ADFA were amalgamated and now IS is taught within the School of Information Technology and Electrical Engineering. This year, the IS staff members have started to provide Vocational Education and Training (VET) level training in Enterprise Architecture under contract to the Department of Defence. They have established a specialist stream in the MSc (IT) for Enterprise Architecture, the first in Australia. They also provide a service course to the second year students in the School of Business (about 25 students).

Despite being part of the UNSW, the IS group at ADFA has little contact with the School of Information Systems, Technology and Management in the Faculty of Commerce at the main campus at Kensington, NSW.

\section{The Australian National University (ANU)}

At ANU, Information Systems has been part of the Faculty of Economics and Commerce since courses in IS were first taught. An early influence was Ron Weber who had an appointment in the then Department of Department of Accounting and Public Finance in 1977-1978. Professor Weber had just completed his PhD at the University of Minnesota and has been identified as the first Australian to obtain a $\mathrm{PhD}$ in IS. He recalls that at that point there were few openings for an information systems academic and he had to rely on his background in accounting and auditing to get a job. Information Systems appears to have been first taught as a separate unit in 1982-1983, by Michael McCrae and Roger Debreceny. In 1984 the Faculty made the strategic appointment of a Reader in Information Systems. Roger Clarke led the discipline until 1995. Joan Cooper was also a Reader in the Department, 1990-1992.

The decade 1984-1995 was marked by growth. A major was jointly developed with the separate Computer Science department, and successful joint Bachelor of Information Technology programs were introduced. These programs ranged from highly technical to highly business-oriented programs, and were linked to the Bachelor of Science and Bachelor of Engineering at one end, and the Bachelor of Commerce and Bachelor of Economics on the other. The foundations for a comprehensive postgraduate program were laid, four $\mathrm{PhD}$ supervisions were completed, and external research grants were awarded by bodies including the ARC.

From 1995 a number of pressures meant that the discipline contracted. Although the number of IS staff at one point briefly reached five, a number left in the mid-1990s. The Faculty made no senior appointment, and for the next five years the discipline languished. By 2000, the group had shrunk to just two staff. At that time the Dean of the Faculty, Professor Tim Brailsford, showed confidence in the future of information systems and electronic commerce and appointed the first Professor of Information Systems, with an endowment from the central administration.

The group has now increased so that there are eight staff and a good number of $\mathrm{PhD}$, Masters and Honours students. Research activity has increased considerably, with much output over the last few years. As at other institutions, research is driven by staff interest and grant funding. This has led to significant diversity in research output, with key papers in areas such as the philosophy of 
technology, technology adoption and use, decision making, business ethics, open source software and market modeling.

The ANU also has a College of Engineering and Computer Science which offers programs in information technology (IT), computer science and software engineering. The IS group works with the IT staff in offering joint degrees and in course specification and design.

\section{University of Canberra (UC)}

IS is a discipline in the School of Information Sciences and Engineering alongside network engineering, Software Engineering and Mathematics and Statistics. The School is in a Division with the Business and Law Schools. UC has two other divisions, Communication and Education and Health, Design and Science.

Computing was a founding discipline at UC when the institution was created as a College of Advanced Education in 1971. The major in-house course for IT in the Commonwealth Public Service, the Programmer-in-Training program, became the core of the computing degree, initially as part of the School of Administrative Studies. The foundation head was Digby Pridmore and within three years computing became a separate school. Information Systems has always been organisationally co-located with the technologists who can reify designs rather than with the user areas. This has allowed a concrete, effective approach to IS teaching and research rather than IS being an abstract discipline that 'someone else can actually do'. Staff initially did not belong to streams such as software engineering, IS or computer hardware; rather they taught in one or more of many computing areas.

Separation has never been complete and IS is core to the Bachelor of Software Engineering and BIT as well as its own program, the Bachelor of Business Informatics. IS continues to teach a significant major into the business program and the major is available to the rest of the university, particularly attracting education students who want to become IT teachers. It also continues to teach its introductory unit into all disciplines. The post-graduate picture is similar with IS teaching into the MIT as well as establishing the MBI and teaching into the MBA, M. Knowledge Management and so on.

In its 30 year history IS has remained with its sister IT disciplines through a range of reorganisations. This history has allowed IS at UC to integrate information, workflow and knowledge management to complement the traditional data management in organisations. There are some areas in UC that teach IS-like units (the Communications school teaches knowledge management and multi-media, the Resources school teaches GIS, marketing teaches some Internet, Education some e-learning and so on). Mostly this teaching is coordinated with the IS program.

Since becoming a university in 1990 UC has emphasised its research program and has reached supervisory saturation point. 


\section{DISTINCTIVE FEATURES OF IS CURRICULUM}

Table 3 gives an overview of the programs offered at the three universities.

\begin{tabular}{|l|l|l|}
\hline University & Undergraduate Courses/programs & Postgraduate Courses/Programs \\
\hline UNSW@ADFA & BSc, BA, service to BBus & $\begin{array}{l}\text { MSc (IT), including streams in } \\
\text { Enterprise Architecture and } \\
\text { Governance }\end{array}$ \\
\hline $\begin{array}{l}\text { The Australian National } \\
\text { University (ANU) }\end{array}$ & $\begin{array}{l}\text { MInfSysSt } \\
\text { MInfSys }\end{array}$ \\
\hline University of Canberra (UC) & $\begin{array}{l}\text { BSE, BIT, BBI*, IS Major, double } \\
\text { degrees eg B.Comm/BBI; } \\
\text { BSE/BBI, BBI/Law }\end{array}$ & MIT, MBI \\
\hline
\end{tabular}

$* \mathrm{BI}=$ Business Informatics

Table 3: Courses from which IS students are drawn as of 2005

\section{Australian Defence Force Academy (ADFA)}

UNSW@ADFA follows the ACM/ AIS Curricula for its undergraduate and postgraduate courses. It reviews its curriculum every three years, with the last review in 2002. As the third year designed by that review has just finished, so another review is just starting.

The IS group within the School uses problem-based learning as much as possible within its undergraduate courses. There is an emphasis upon systems thinking, including Alter's 'work systems' concepts (as represented by the third year subject Managing Work Systems). The components of IT are not discussed until the Operating Information Systems in second year. However, all first year students are expected to pass the International Computer Drivers Licence made available through ACS.

There are no electives in the IS minor course and only one elective in the IS major. All students are required to undertake a project in the third year that acts as a capstone for the course.

The postgraduate courses are taught using 'flexible education'; that is, classes are available on campus but most of the students are distance students. WebCT is used to manage the courses, with student notes delivered as Word documents linked to WebCT or to a student Portal for some subjects.

\section{The Australian National University (ANU)}

The undergraduate IS curriculum is based on the Australian Computer Society (ACS) accreditation guidelines. Major curriculum reviews occur approximately every three years, with minor revisions occurring on a yearly basis. Staff levels have historically dictated the number of course offerings available, though recent increases in staff levels have meant more specialised classes can be offered at both graduate and undergraduate levels.

Because of the group's proximity to the business disciplines, course delivery is frequently undertaken from a business and commercial perspective. Key undergraduate courses are offered in Information Systems Foundations (encompassing Knowledge Management, Decision Support 
Systems, Design, and Ethics), Electronic Business, Analysis and Design, Information Systems Management and Project Management. Graduate level courses are offered in IS Research Issues, eCommerce for Managers, Strategic Information Systems, Communications Technologies and Issues in Organisational Information Systems. Staff are encouraged to take their own approach to delivering course content, guiding students and providing pastoral care. This approach includes sharing course tutelage between staff members in order to support different perspectives and teaching styles.

The combined four-year BIT/BIS degree program that gives both a business-focused IS major as well as the more technical knowledge in the IT major offered by the Department of Computer Science has been very popular with students until recently.

All undergraduate courses maintain at least one course website. Content portals vary between staff members, classes and year levels. Some courses in the school use WebCT to manage and provide course content, while others maintain their own content web sites under a Faculty web server model. Some courses are also using weblogs to furnish class content.

\section{University of Canberra (UC)}

IS at UC takes the position that there is a core of IS knowledge and that this facilitates responsible and effective technology-based systems creation and adoption by a wide range of professional disciplines. Business is one application area, and UC runs courses at undergraduate and postgraduate levels in 'business informatics' that combine IS and business. The IS group also teaches into areas including Health Informatics and Educational Informatics, but to date with much lower numbers than for Business. On the technology side, IS has majors and electives in the Bachelor of Information Technology and Bachelor of Software Engineering and a combined BBI/BIT course

The IS core comprises typical IS units (Information Systems in Organizations, Database Design, Human Computer Interaction, Systems Analysis and Modeling, Document and Workflow Management, Systems Project and Quality Management) plus electives (in Human Computer Interaction, Usability Evaluation, Knowledge Management Systems, Business Intelligence Systems, Database Systems, Advanced Information Modelling, General Systems Theory, IS Management, Business Informatics Case Studies, Information Security, Information Law and IT and Business Alignment).

The development of students who have an understanding of the interpersonal and group processes required of IS and IT professionals is a feature of IS teaching at UC. Students engage in group projects, role-playing case studies, online virtual organisations and presentations and they develop visual and written communication skills, critical thinking and teamwork skills.

All units are required to show how they embody a) current research literature, b) appropriate IT, c) industry participation and d) pedagogical technique. All units have a website for teaching material and to facilitate communications. Units are developed by teams and each academic is on several teams in order to keep the unit content coherent. Academics are encouraged to develop new units in the areas of their research.

Industry interaction is important so UC has tutors and guest lecturers drawn from industry, panels to advise on curriculum content and the IS group teach into specific industry courses (for example, with the Australian Bureau of Statistics and Kaz Computing). The BIT has an industry project and 
the Bachelor of Business Informatics has an industry-supported internship that is becoming a significant vehicle for industry interaction.

\section{DISTINCTIVE FEATURES OF IS RESEARCH}

Table 4 shows the main areas of research interest in the Information Systems groups in each of the universities.

\begin{tabular}{|l|l|l|}
\hline University & Areas of IS Research Focus & IS Research Groupings \\
\hline $\begin{array}{l}\text { AustralianDefence Forces } \\
\text { Academy }\end{array}$ & $\begin{array}{l}\text { Governance, DSS for crisis/ anti- } \\
\text { terrorist management, Risk } \\
\text { management, Tools for human } \\
\text { thinking }\end{array}$ & $\begin{array}{l}\text { Virtual Environment and } \\
\text { Simulation Laboratory (part), } \\
\text { Decision Support } \\
\text { ICT Governance and Enterprise } \\
\text { Architecture group } \\
\text { (see ADFA, 2005c) }\end{array}$ \\
\hline $\begin{array}{l}\text { The Australian National } \\
\text { University }\end{array}$ & $\begin{array}{l}\text { Strategic use of IT, Technology } \\
\text { adoption, Intelligent } \\
\text { systems/decision support, Human- } \\
\text { computer Interaction, Project } \\
\text { Sanagement, Theoretical } \\
\text { foundations, Open Source } \\
\text { Software }\end{array}$ & \\
\hline University of Canberra & $\begin{array}{l}\text { HCI, Ethics, Ontology \& Systems } \\
\text { Modelling, virtual behaviour, } \\
\text { informatics (e-research, e-learning, } \\
\text { health informatics, e-law) }\end{array}$ & $\begin{array}{l}\text { Human-Computer Communication } \\
\text { Laboratory, } \\
\text { Informatics Program } \\
\text { (see UC, 2005b) }\end{array}$ \\
\hline
\end{tabular}

Table 4: Information Systems Research in ACT Universities

\section{Australian Defence Force Academy (ADFA)}

The UNSW@ADFA IS group prefers the ‘design theory’ approach to research, which focuses on knowledge and theory concerning effective methods and structures for the development of information systems. All of its members have consultancy and ICT industry backgrounds, so they favour the development of tools and techniques that are useful and usable. These group members undertake several consultancies each year, which often act as feedstock for their research papers.

Generally, the IS group members avoid applying for external grants. They prefer to obtain industry funding for their research, usually in the form of consultancy activity, which can form the basis for papers about how the work was undertaken.

The research interests of the members of the IS group include systems planning (business cases, tender evaluation), Enterprise Architecture, ICT governance (strategic planning, performance measurement), aids to human decision-making, social networks, value systems, viable systems theory, household information systems, and e-government. The members of the group work with other staff of the School in gaming, complex systems, and optimisation. 


\section{The Australian National University (ANU)}

The ANU group is very active in research. The primary research concerns through the 1980s were in the areas of accounting applications, software development and project management. During 1988-95, the Department ran a major research program in Supra-Organisational Systems. Particular foci included strategic information systems, EDI and other emergent forms of e-commerce, and the economics of AARNet and the then-new public Internet.

Staff have recently been increasingly successful in obtaining grants, with a number of ARC grants and applied research projects with government and industry. As an example, members of the group completed a large applied research project in 2005 commissioned by the Department of Communications, Technology and the Arts (DCITA) concerning the realisation of value from information and communication technologies. The report from this project was launched by the Minister responsible for DCITA, Helen Coonan, in Sydney in April, 2005 and copies of the report have been distributed nationally in conjunction with the Australian Computer Society.

The group aims to focus on research issues that are of fundamental importance to the IS discipline and to this end hosts a biennial workshop on "Information Systems Foundations". The National Centre for Information Systems Research (NCISR), formerly known as the Electronic Commerce Research Group, is a vehicle for collaborative research within the IS group. Members include other Faculty staff as well as external researchers and business figures. The Centre has a regular seminar program that is designed to be of interest to a wide range of people.

\section{University of Canberra (UC)}

In the 15 years since UC became a university IS research has been largely individual and therefore eclectic. Most of the IS staff come originally from industry, but have been in the education field for some time. Of the 11 staff, 5 have PhD's and 2 are enrolled. The group is roughly half active researchers, a quarter occasional researchers and a quarter who are not research active.

In ARC terms the research is not strong, but there is a history of work in human-computer interaction, modeling, ethics, IT education and e-government. Much of the research work is done in collaboration with Commonwealth Government agencies and semi-government organisations such as Greening Australia and Kaz Computing.

The Informatics theme is an attempt to bring the group's research work into a coherent framework, in particular, to Research Informatics (or e-Research, being the application of ICT to the research process and the use of its products), e-learning, e-law and health informatics.

The development of two research coursework units, Research Proposal and Research Methodology, and the weekly research seminar series have assisted in giving research students a better grounding and provided a forum for staff and visitor interaction with research students. 


\section{KEY FIGURES WHO HAVE INFLUENCED IS IN ACT UNIVERSITIES}

It is not possible to include all the people who have contributed to IS within the ACT and just a few key people are included. Some background for each of the three authors is included as each is currently a leader of IS at one of the three universities and so have some degree of influence on what is happening and has happened, for varying lengths of time.

\section{Australian Defence Force Academy (ADFA)}

Dr Edward Lewis has taught IS at UNSW@ADFA since 1986. After 12 years in the Australian Army, working in IS policy and personnel areas, he was posted to the Academy as a Visiting Military Fellow (effectively an academic in uniform). He converted to civilian life in 1988, after realising that being an academic "sure beats working for a living”. He taught every subject as the curriculum developed from first year through to the introduction of the Honours year in 1991. He supervised the first three Honours students in that year, as well as the first MSc and PhD students, also starting in that year. Until this year, as the only IS staff member with a PhD, he has supervised all of the seven $\mathrm{PhD}$ graduates in IS and is currently supervising 12 postgraduate students. Dr Lewis is active in consulting projects, mostly in strategic planning, business cases, and thinking tools. He is currently the chair of the IT-030 Committee for Standards Australia that recently published AS8015: 2005 Corporate Governance of information and communication technology and AS8018: 2004 ICT Service Management.

\section{The Australian National University (ANU)}

Dr Roger Clarke led the establishment of IS at the ANU, where he was a Reader in the Department of Commerce from 1984 to 1995. Roger has also made his mark more widely. He founded the Australasian IS Directory in 1988, was a Foundation Committee-member of the Australasian Conference in Information Systems (ACIS) 1991-94, was a Foundation Asia-Pacific Councillor of the AIS in 1995-96, and established the ISWorld Country Section, including the page for Australia, in 1996. He returned to consultancy in 1995, focussing on strategic and policy aspects of ebusiness, information infrastructure, and dataveillance and privacy and is now a Visiting Professor at ANU's Department of Computer Science.

Dr Shirley Gregor came to the ANU in 2001 as the Foundation Professor in Information Systems and was given the role of developing the strengths of the Information Systems group. Shirley began her career as a Programmer-in-Training in Melbourne and had a number of years in the computing industry in Australia and the United Kingdom before becoming an academic. Professor Gregor was inaugural President of the Australasian Association of Information Systems 2002-2003 and is VicePresident of the Australian Council of Professors and Heads of Information Systems. Professor Gregor was made an Officer of the Order of Australia in the Queen's Birthday Honours list in June 2005 for services as an educator and researcher in the field of information systems and in the development of applications for electronic commerce in the agribusiness sector. At the ANU she has focused on facilitating research through the formation of the National Centre for Information Systems Research.

\section{University of Canberra (UC)}

Dr. Igor Hawryszkiewycz was head of IS during the late 1970's and early 1980's and is now a Professor at the University of Technology, Sydney, specialising in collaborative technologies. 
Dr Errol Martin was an Associate Professor and Head of the School in which IS was located in the late 90's. He maintained strong links with industry and chaired the ACS IS Board for many years.

Penny Collings has been a long-time teacher and researcher at UC after specialising in computer supported collaborative learning and behavioural simulations. She became the head of the IS discipline (1992-2001) and is responsible for the development of several industry-based panels that provide input into the course redesigns that occur every three years.

Dr Craig McDonald has been Head of IS since 2001. He spent 15 years in industry before moving to the university sector in 1985. He has conducted innovative research and practical application of knowledge management and expert systems to support the viticulture industry with the CRC Viticulture and currently publishes in ethics, e-research and concept modelling. Dr McDonald is currently Editor of the Australasian Journal of Information Systems.

Dr John Campbell joined UC as ISE Research Director in 2005. Prior to his current appointment, he spent 17 years at Griffith University in Brisbane where his responsibilities included Head of School in Information Systems and Management Science, and also as Deputy Head of School in the School of Management. His major research focus is how users interact through information systems in the social world and, in particular, the ways in which organisational decision-making and community interaction are enacted through collaborative technologies. Since 2001, he has assumed an active member role in CPA Australia’s Information Technology and Management Centre of Excellence.

\section{The Status of IS as a Distinct Discipline in ACT Universities}

The status of IS in the ACT universities is analysed against the framework contributed by Ridley (2006) as a common basis for comparison for the cases in this volume. This framework encompasses the following dimensions:

The nature of the "body of knowledge" in the disciplinary units, where the knowledge could be of the types distinguished by Fitzgerald (2003), that is, rules or laws (as in the natural sciences); evidenced guidelines; and normative guidelines.

The degree of professionalisation of the discipline, which is expected to decrease as the impact of local contingencies increases. The degree of professionalisation will be evidenced by the extent of variation in the nature of IS research.

The acceptance as a distinct scientific field, which is conditioned on:

scientific reputations becoming socially prestigious and critical rewards controlled;

standards of research competence and skills being established

a unique symbol system is developed that allows the exclusion of outsiders.

We have used this framework in our analysis, although we do not necessarily endorse the use of the word "science" or "scientific" to describe the IS discipline. This is not to say that IS research should not be rigorous, but the word science has many connotations and at least some of the work done in IS does not conform to common understandings of what makes a science, in terms of the natural and behavioural sciences (for example, see Nagel, 1979). 


\section{NATURE OF 'BODY OF KNOWLEDGE'}

The domain of knowledge is examined by analysing the commonalities in syllabi across all three institutions. Table 5 below shows the areas of knowledge that are common across all of the three universities in the core knowledge in their information systems majors. Two of the three universities follow Australian Computer Society guidelines in planning their curriculum but these guidelines, as described in Underwood (1997), leave a great deal of discretion to the institution applying them.

\begin{tabular}{|c|c|c|c|}
\hline $\begin{array}{l}\text { ACS core knowledge area } \\
\text { nomenclature }\end{array}$ & $\begin{array}{l}\text { ADFA course } \\
\text { (IS major in BA, BSc) }\end{array}$ & $\begin{array}{l}\text { ANU course } \\
\text { (IS major in BComm) }\end{array}$ & $\begin{array}{l}\text { UC course } \\
\text { (IS Major) }\end{array}$ \\
\hline Introductory Unit $^{* *}$ & $\begin{array}{l}\text { Introduction to } \\
\text { Information Systems } \\
\text { (problem solving } \\
\text { approach) }\end{array}$ & $\begin{array}{l}\text { Foundation of } \\
\text { Information Systems } \\
\text { and E-Commerce }\end{array}$ & $\begin{array}{l}\text { Information Systems in } \\
\text { Organisations }\end{array}$ \\
\hline $\begin{array}{l}\text { Program Design and } \\
\text { Implementation (or } \\
\text { Systems Building/Software } \\
\text { construction) }\end{array}$ & $\begin{array}{l}\text { Exercises in Perl within } \\
\text { IS in Organisation; Web } \\
\text { design within Design of } \\
\text { IS }\end{array}$ & $\begin{array}{l}\text { Introduction to } \\
\text { Programming }\end{array}$ & $\begin{array}{l}\text { Use of SQL in } \\
\text { Database Design and } \\
\text { system building in IT } \\
\text { Project. Some use of } \\
\text { design tools in } \\
\text { Designing Human } \\
\text { Computer Interaction } \\
\text { and Systems Analysis } \\
\text { \& Modelling }\end{array}$ \\
\hline $\begin{array}{l}\text { Systems Analysis and } \\
\text { Design }\end{array}$ & Design of IS & $\begin{array}{l}\text { Information Systems } \\
\text { Analysis }\end{array}$ & $\begin{array}{l}\text { Systems Analysis \& } \\
\text { Modelling, Advanced } \\
\text { Information } \\
\text { Modelling, } \\
\text { Document and } \\
\text { Workflow } \\
\text { Management, } \\
\text { Knowledge } \\
\text { Management Systems }\end{array}$ \\
\hline Database Management & $\begin{array}{l}\text { IS in Organizations and } \\
\text { Design of IS }\end{array}$ & $\begin{array}{l}\text { Relational Databases, } \\
\text { Database Systems }\end{array}$ & $\begin{array}{l}\text { Database Design, } \\
\text { Database Systems }\end{array}$ \\
\hline $\begin{array}{l}\text { Project Management and } \\
\text { Quality Assurance }\end{array}$ & $\begin{array}{l}\text { Selection of Systems, } \\
\text { Management of Work } \\
\text { Systems }\end{array}$ & $\begin{array}{l}\text { Project Management } \\
\text { and Information } \\
\text { Systems }\end{array}$ & $\begin{array}{l}\text { Systems Project and } \\
\text { Quality Management }\end{array}$ \\
\hline $\begin{array}{l}\text { Managerial and } \\
\text { organizational issues }\end{array}$ & $\begin{array}{l}\text { Management of Work } \\
\text { Systems }\end{array}$ & $\begin{array}{l}\text { Information Systems } \\
\text { Management }\end{array}$ & $\begin{array}{l}\text { IS Management, IT } \\
\text { Business Alignment }\end{array}$ \\
\hline Specialist areas $^{* *}$ & $\begin{array}{l}\text { Application of IS } \\
\text { (elective choice of } \\
\text { topics, including e- } \\
\text { Commerce, Data } \\
\text { Management) }\end{array}$ & $\begin{array}{l}\text { Electronic Business, } \\
\text { Accounting } \\
\text { Information Systems, } \\
\text { Electronic Commerce } \\
\text { Strategic Issues, } \\
\text { Information } \\
\text { Technology in } \\
\text { Electronic Commerce }\end{array}$ & $\begin{array}{l}\text { Document and } \\
\text { Workflow } \\
\text { Management, } \\
\text { Knowledge } \\
\text { Management Systems, } \\
\text { Business Intelligence } \\
\text { Systems, General } \\
\text { Systems Theory, } \\
\text { Informatics Case } \\
\text { Studies }\end{array}$ \\
\hline $\begin{array}{l}\text { Ethics/social } \\
\text { implications/professional } \\
\text { practice }\end{array}$ & $\begin{array}{l}\text { IS in Organisations, } \\
\text { Management of Work } \\
\text { Systems }\end{array}$ & In many courses & $\begin{array}{l}\text { In many courses, } \\
\text { especially IT Project }\end{array}$ \\
\hline
\end{tabular}




\begin{tabular}{|l|l|l|l|}
\hline $\begin{array}{l}\text { Interpersonal } \\
\text { communications }\end{array}$ & $\begin{array}{l}\text { Introduction to IS, } \\
\text { Management of Work } \\
\text { Systems, } \\
\text { IS Project - all courses }\end{array}$ & In many courses & $\begin{array}{l}\text { Throughout. Specialist } \\
\text { unit (Professional } \\
\text { Practice in IT) for } \\
\text { international students }\end{array}$ \\
\hline Industry Project & $\begin{array}{l}\text { Third year team project, } \\
50 \% \text { load second } \\
\text { semester, from Defence }\end{array}$ & $\begin{array}{l}\text { Project Management } \\
\text { and Information } \\
\text { Systems }\end{array}$ & $\begin{array}{l}\text { IT Project; Business } \\
\text { Informatics Internship }\end{array}$ \\
\hline
\end{tabular}

*The Australian Computer Society’s Core Body of Knowledge terminology unless noted.

${ }^{* *}$ Not named as such in the ACS Core Body of Knowledge

Table 5 Knowledge areas common to the core of Information Systems at all three universities.

However, from Table 5 it can be seen that there is some commonality across the institutions in the core of their courses, which is evidence of common understanding of the domain knowledge which is central to the discipline. The areas in common include systems analysis and design, database design and management, project management, managerial and organisational issues, ethics/social implications/professional practice and interpersonal communications. Each university provides coverage of specialist knowledge and application areas that reflect the interests and capabilities of staff.

There is variation in the degree to which programming and software construction are required. At ANU an introductory programming course is mandatory. UNSW@ADFA provides little education in programming in its IS courses, with its computer science programs covering programming in more depth. The main reason is that the careers of the undergraduates are prescribed and they involve no programming on the job, rather the supervision of civilian or service trade-trained personnel. UC requires no mandatory programming study, which again is covered in information technology programs, but students do get experience of systems building in their project courses. Another lack of commonality concerns Data Communications and Networks, which is a mandatory course only at ANU.

There is a range in the types of knowledge presented in the courses taught in common. In the terms of Fitzgerald (2003):

Rules or laws (as in the natural sciences). Examining the common syllabi shows that there is relatively little core knowledge of the natural science type - there are few, if any, law-like generalisations. Rather the knowledge falls more into the second and third categories in Fitzgeralds's taxonomy below. The knowledge, however, does rely on underlying theories of the natural science type for justification and explanation of system-building knowledge. For example, guidelines for the construction of decision support systems rely on behavioural science knowledge of human decision making.

Evidenced guidelines. The common syllabi include knowledge that in the form of guidelines arising from practice. For example, the project management courses include knowledge of project management tools and practices such as software cost estimation that are based on empirical observation.

Normative guidelines. The courses in the common syllabi include what can be termed normative guidelines or 'design theory' (see Gregor, 2002, 2006). For example, Codd's relational database theory is taught in all the database courses across the institutions. 
Our conclusion is that we have a recognised common domain that might be expressed in this way: the Information Systems discipline analyses human activity, determines the kinds of data, information and knowledge needed to enable people to act effectively and responsibly, designs technology-based systems to support them and evaluates the impact of those systems.

Our knowledge is based on theories of information, human activity and organisations, IS studies analysis techniques and methodologies, human-computer interaction, data and knowledge representation and design, systems construction and validation, and the impacts of systems on people, organisations and society. In this unique role IS bridges the essentially content-free information technologies with the content-rich but often unstructured domain knowledge.

To perform this function, IS embraces types of knowledge and epistemologies that differ from those traditional in the natural sciences and exhibits a more well-grounded, participative style congruent with a discipline that is at the intersection of science, technology and human and organisational behaviour.

\section{DEGREE OF PROFESSIONALISATION}

Our reflection leads us to conclude that we have a relatively low degree of professionalisation of the discipline, using the criteria of the "extent of variation in the nature of IS research".

In terms of the content of our research endeavours there is not a great deal of variation, as all our researchers focus on areas which are recognisably within the disciplinary bounds, and we have common understanding of each other's interests. A number of the people in our schools (and all the authors) do applied research, in that we build or help people to build artifacts.

However, in terms of the methods used in our research there is very wide variation and the research methods taught to students do not necessarily suit the particular nature of IS as, at least in part, a discipline concerned with the construction of artifacts (as evidenced in our common syllabi). The IS students at ANU are taught research methods in the same class as accounting, auditing, management and marketing students and do not currently have any exposure in these courses to "design theory" (a shortcoming to be addressed in the near future). The situation at ADFA is similar, with only UC explicitly addressing design-type research. This disjoint between what is taught as core knowledge and what is taught as research methods leads us to conclude that there is a low degree of professionalisation.

\section{ACCEPTANCE AS A DISTINCT FIELD}

The consensus of opinion among the authors is that our field is not 'socially prestigious'. All of us have had experience with appointment and promotion committees where it is clear that the nature of work in IS is not well understood or regarded highly. Many of our staff have had experience in industry before joining in academia so they have had relatively limited time to establish a scientific reputation in terms understood by committees with social and physical scientists who have worked almost their whole career in universities.

Neither are we accepted as a distinct field in terms of a unique symbol system by outsiders. We do have commonalities in our symbol system with parts of computer science and software engineering, which is understandable as we are allied fields with some degree of overlap. However, we have 
overlap which is of more concern in that much of our symbol system is also used by people in application areas who use IS and IT as tools. We find it hard to 'exclude these people as outsiders' and many cannot see why they should not teach IS topics within their own areas, as in Health Informatics. People outside IS, even within universities, have very poor understanding of what the term "information system" means, either in relation to the artifacts constructed, or as name of the discipline. The continuing debate within IS about how our discipline should be defined only adds to the confusion.

To conclude, each of the universities has a vibrant IS group which appears happy with the work they do themselves. There are areas of concern, however, reflected in the different organisational placements of each groups and the disciplines with which they most interact within their university. It would be hard to argue that the groups have an unambiguous identity visible to those outside the groups.

\section{REFERENCES}

ADFA (2005a) http://www.unsw.adfa.edu.au/

ADFA (2005b) School of ITEE http://www.itee.adfa.edu.au/

ADFA (2005c) ITEE Research www.itee.adfa.edu.au/research/

ADFA (2005d) Portal www.itee.adfa.edu.au/ ejl/Portal

ANU (The Australian National University) (2005a). 2005)

http://info.anu.edu.au/discover_anu/About_ANU/Profile/index.asp (Accessed Sept.,

ANU (The Australian National University) (2005b).

http://info.anu.edu.au/Discover_ANU/About_ANU/Vice-

chancellor_XXs_Welcome/index.asp

(Accessed Sept., 2005)

Fitzgerald, G. (2003) Information Systems: A subject with a particular perspective, no more, no less, European Journal of Information Systems, Vol.12, No.3, pp. 225-228.

Gregor, S. (2006, forthcoming). The nature of theory in information systems. MIS Quarterly, 30, 3.

Gregor, S. (2002). Design theory in Information Systems. Australian Journal of Information Systems, Special Issue, 14-22.

Nagel, E. (1979). The Structure of Science, Hackett Publishing Co., Indianapolis, IN.

Ridley, G. (2006). Characterising Information Systems in Australia: A Theoretical Framework, (see this issue)

UC (University of Canberra) (2005a) http://wwww.canberra.edu.au/

UC (University of Canberra) (2005b) ISE Research http://www.canberra.edu.au/schools/ise/research/

Underwood, A. (1997). The Core Body of Knowledge for Information Technology Professionals, Australian Computer Society. http://www.acs.org.au/national/pospaper/bokpt1.htm

Whitley, R. (1984). The Intellectual and Social Organization of the Sciences, Clarendon Press, Oxford, UK. 


\section{THE AUTHORS}

Professor Shirley Gregor is Head of the School of Accounting and Business Information Systems at ANU. Professor Gregor spent a number of years in the computing industry in Australia and the United Kingdom before beginning an academic career. Her current research interests include the adoption and strategic use of information and communications technologies, intelligent systems and human-computer interface issues, and the theoretical foundations of information systems.

Dr Ed Lewis is a Senior Lecturer at the Australian Defence Forces Academy (ADFA). Dr Lewis was in the Australian Army for 12 years before being posted to ADFA. His research interests include methods for enhancing human problem-solving, the development of planning tools, including Risk-Remedy, preparation of business cases, tools for tender evaluation and the design of information management strategy and policy.

Dr. Craig McDonald is Associate Professor of Information Systems at the University of Canberra. For nearly four decades he has been developing, teaching, researching and consulting in systems that manage data, information and knowledge. These systems have been in the public service, NGOs, private enterprise and in research organisations. His current work is in e-Research, ontologies, informatics and applied ethics.
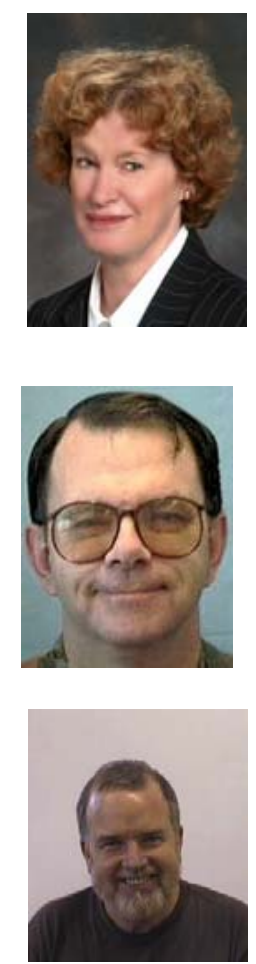